\title{
Vessel operator response to a voluntary measure for reducing collisions with whales
}

\author{
Gregory K. Silber*, Jeffrey D. Adams, Shannon Bettridge \\ Office of Protected Resources, National Marine Fisheries Service, National Oceanic and Atmospheric Administration, \\ Silver Spring, Maryland 20910, USA
}

\begin{abstract}
Voluntary programs have been used with varying degrees of success to address a variety of environmental issues. The goal of the present study was to assess mariner response to a voluntary program to reduce the threat of vessel collisions with the endangered North Atlantic right whale Eubalaena glacialis. The program involves the creation of temporary zones, dynamic management areas (DMAs), in which vessel operators are requested, but not required, to either navigate around the area or travel through at speeds of 10 knots or less. Using remotely sensed automatic identification system data, we analyzed 3324 transits made by 1100 individual vessels, the majority of which belong to the international commercial shipping industry utilizing east coast ports of the USA. In general, we observed very little change in vessel operations in response to the DMAs. The mean transit speeds for cargo, tanker, and passenger vessels within the DMAs exceeded the requested maximum of 10 knots and differed little from speeds used outside DMAs. In addition, few transits appeared to involve efforts to navigate around the DMAs. Therefore, we conclude that the program likely had only a modest consequence in reducing vessel collisions with whales, at least as measured by vessel operations. These results may have application to other settings where voluntary programs are contemplated or implemented.
\end{abstract}

KEY WORDS: Vessel-whale collisions · Voluntary conservation programs · Right whale

\section{INTRODUCTION}

The use of voluntary programs to address environmental issues has grown dramatically (e.g. EEA 1997, Barde 2000, Alberini \& Segerson 2002, NRC 2002, Morgenstern \& Pizer 2007). They are often preferable to regulatory actions because they can be implemented relatively quickly (Morgenstern \& Pizer 2007); do not require the development of potentially costly monitoring, policing, and penalty regimes; are less prone to litigation; and can promote innovation within the affected community (Khanna 2001, Rivera \& de Leon 2004). However, public participation is essential to voluntary programs achieving their intended goals. Voluntary environmental protection programs have been used in such diverse areas as improvement of air quality and reduction of various industrial chemical emissions (Khanna \& Damon 1999, Gamper-Rabindran 2006), adoption of energyefficient technologies and reduction of carbon dioxide emissions (Morgenstern \& Pizer 2007), and waste management (Lyon \& Maxwell 2007). They have also been used in protection of ecosystem diversity and endangered species (e.g. FWS/NMFS 1997, Smith \& Shogren 2002, Mönkkönen et al. 2009).

Various attempts have been made to address a specific environmental issue involving endangered marine species: the threat of at-sea vessel collisions with large whale species (Wiley et al. 2008, Vanderlaan et al. 2009, Silber et al. 2012). Vessel collisions 
with whales occur in all oceans. They can involve all large whale species and nearly all vessel classes, and are often fatal to the whale (Laist et al. 2001, Jensen \& Silber 2003). Nearly 800 records of vessel collisions with large whale species are described in the scientific literature (Van Waerebeek et al. 2007). These counts should be regarded as minima, as many collisions go undetected or unreported (Kraus et al. 2005), the cause of death cannot always be determined in a beach-stranded carcass (Glass et al. 2010), and reporting is inconsistent in many areas.

Efforts to reduce the threat of vessel collisions with whales have included both mandatory and recommended changes in vessel-routing practices, including the establishment of 'Areas To Be Avoided' in both Canadian (Vanderlaan \& Taggart 2009) and US waters (Silber \& Bettridge 2006, Silber et al. 2012), and the modification of vessel traffic separation schemes in US and Mediterranean waters (Tejedor et al. 2007, Silber et al. 2012). The goal of these vessel-routing modifications is to reduce the threat of collisions by reducing the overlap of high density vessel traffic and whale aggregation areas. Mandatory and recommended restrictions of vessel speed have also been employed to minimize the threat of collisions with whales (NPS 2006, NOAA 2008a,b, Tejedor Arceredillo et. al. 2008). Studies have indicated that as vessel speeds diminish so does the likelihood of serious injury or death when a whale is struck by a vessel (Laist et al. 2001, Pace \& Silber 2005, Vanderlaan \& Taggart 2007).

For the highly depleted North Atlantic right whale Eubalaena glacialis, which is listed as Endangered under the US Endangered Species Act (ESA) and as depleted under the Marine Mammal Protection Act (MMPA), collisions with ships (or 'ship strikes') is one of the species' greatest threats to recovery (Kraus et al. 2005). In a population containing only several hundred individuals, an average of about 2 known (others almost certainly go undetected) vessel collision-related right whale deaths have occurred annually over the last decade (Glass et al. 2008, 2010, Waring et al. 2010). To address this threat, the US National Oceanic and Atmospheric Administration's (NOAA) National Marine Fisheries Service (NMFS) issued a final rule requiring vessels 65 feet (ca. $20 \mathrm{~m}$ ) or greater in length to travel at 10 knots or less during certain times of the year in locations (termed 'seasonal management areas' [SMAs]) along the US eastern seaboard that are characterized by right whale occurrence and concentrated maritime activity (NOAA 2008b). In combination with these manda- tory restrictions, the NMFS also established a program whereby temporary zones, called 'dynamic management areas' (DMA), can be established quickly in locations throughout the species' range when right whales are observed outside of the geographic extent or effective period of the SMAs (NOAA 2008b). The SMA and DMA programs provide complementary protective mechanisms responsive to both the predictable, as well as the unexpected and transitory presence of right whales.

Because the range of the right whale includes all coastal waters of eastern North America, DMAs might be created in any location along the US eastern seaboard (Asaro 2012). They are established when reliable sightings are obtained (derived primarily from systematic aircraft surveys for marine mammals using trained observers) of 3 or more right whales in US waters within a 75 square nautical mile ( $\left.\mathrm{n} \mathrm{mile}{ }^{2}\right)\left(138.9 \mathrm{~km}^{2}\right)$ area, such that right whale density was $\geq 0.04$ right whales $n$ miles $^{-2}$. This is consistent with protocol suggested by Clapham \& Pace (2001), and is based on the assumption that whale groups at those densities would persist for an extended period. Additional (15 n miles $\left.{ }^{2}\right)$ areas are then delineated around the sighting location to account for potential whale movement and are incorporated into a single polygon that encompasses both the sighting location and its surrounding zone. Each DMA is established immediately (i.e. $<24 \mathrm{~h}$ ) upon confirmation of right whale sighting locations and automatically set to expire $15 \mathrm{~d}$ after the initiation date. If whale aggregations persist beyond this period, the DMA may be extended for an additional $15 \mathrm{~d}$. Maritime communities are notified of the existence of a DMA via: NOAA Weather Radio broadcasts on a regular basis for the full duration of the DMA; US Coast Guard (USCG) broadcast notices to mariners; an email distribution list (605 recipients of shipping industry liaisons and industry representatives, pilot associations, harbor masters, marine exchanges, etc.); postings on the NMFS' Office of Protected Resources ship strike web site and the Northeast Fisheries Science Center's web-based interactive right whale sightings system; and an automatic return message via electronic mail is sent to mariners who seek information on whale-sighting locations. Mariners are requested, but not required (i.e. voluntary compliance is encouraged), to either navigate around DMAs or travel through them at 10 knots or less. Given the geographic scope of the DMA program and the number of vessels routinely transiting the US eastern seaboard, this voluntary conservation measure can potentially affect the 
activities of a sizable portion of the commercial shipping industry and other maritime interests including passenger vessels, recreational boaters, and fishing vessels that utilize US east coast ports and waterways.

The goal of the present study was to assess vessel operators' responses to the DMAs. We examined vessel speeds to determine the degree to which vessels were adhering to the requested speed restriction and to detect any changes in speed as they entered the DMAs. We also examined vessel routes to determine the extent to which vessels may have been altering their course to navigate around the DMAs.

\section{MATERIALS AND METHODS}

\section{Automatic identification system}

We assessed mariner response to the DMAs using automatic identification system (AIS) data. Designed as a safety of navigation tool, AIS transponders send global positioning system (GPS)-linked, very high frequency (VHF) (161.975 and $162.025 \mathrm{MHz}$ ) radio signals providing ship-to-shore and ship-to-ship information transfer. The International Convention for the Safety of Life at Sea (SOLAS), an international agreement that specifies minimum standards for the construction, equipment, and operation of vessels, requires that all ships 300 gross tons and greater engaged in international voyages, cargo ships of 500 gross tons and greater not engaged in international voyages, and passenger ships irrespective of size carry AIS equipment. Participating nations are responsible for ensuring that ships operating under their jurisdiction comply with SOLAS requirements. The USCG has codified these requirements domestically by requiring that all vessels 65 feet (ca. $20 \mathrm{~m}$ ) or greater traveling in US waters carry AIS transponders. The AIS signal normally has a range of about 20 to $30+n$ miles (essentially line of sight), but this range may be extended (e.g. depending on the height of the receiving antenna) or diminished in certain circumstances (e.g. electrical storms or certain atmospheric conditions).

AIS transponders send multiple signals each minute that provide a suite of information, both dynamic (unique to a particular voyage) and static (constant for a given vessel). Dynamic information includes the vessel's position (in latitude/longitude coordinates), speed over ground, course over ground, heading, and position accuracy, all of which are determined by continuous GPS-linked updates. Sta- tic information includes the vessel's: name, call sign, type, length, country of origin, and maritime mobile service identity (MMSI) number (a number unique to each vessel assigned for the purposes of navigational safety). All static information is entered by the operator upon initializing the system.

The AIS network operates continuously and autonomously, updates as often as every $2 \mathrm{~s}$, and is capable of handling $>4500$ reports $\mathrm{min}^{-1}$, making it a highly precise means to track vessel operations. The USCG established a network of AIS receivers that covers nearly all US waters. The NMFS's Office of Protected Resources, in cooperation with the USCG and the Department of Transportation's Volpe National Transportation Systems Center, makes use of data feeds from this system (see Silber \& Bettridge 2010 for a detailed description of our AIS data acquisition and analysis).

\section{Vessel operations in DMAs}

We analyzed operations in 66 DMAs that were established between December 2008 and June 2011. Of these, 59 occurred in waters off New England and 7 off the states of Georgia and Florida (Table 1). All but one of the DMAs in New England waters were rectangular in shape, while those occurring in waters off Georgia and Florida tended to be irregular in shape due to their juxtaposition to already in-effect SMAs or broadly distributed whale sighting locations. The locations and frequency of DMAs were influenced not only by the seasonal occurrence of right whales Eubalaena glacialis, but also by a varying amount of aircraft survey effort throughout the year and the DMA protocol itself, which indicates that DMAs not be overlain with established SMAs. DMAs ranged in size from 404 to $4391 \mathrm{n}$ miles $^{2}$ (Table 1). The 59 DMAs in northeastern US waters occurred in all months of the year, with most occurring in November $(\mathrm{n}=6)$, December $(\mathrm{n}=9)$, and January ( $\mathrm{n}=8$ ) (Table 1, Fig. 1). All US southeast Atlantic coast DMAs occurred in January and February, the period of high right whale occurrence in that region.

We quantified the number and types of vessels travelling through the DMAs during their effective period. These counts included only those transits that consisted of at least $1 \mathrm{n}$ mile of travel within an active DMA. Information on 'vessel type' is encoded in the AIS message itself as established by the International Maritime Organization protocol and as entered by the operator. The operator is limited to a finite num- 
Table 1. Characterization of the 66 dynamic management areas (DMAs) analyzed, including: number of whales that prompted the DMA, total area (in square nautical miles, $n$ miles ${ }^{2}$ ), start and end date (month/day/year) of DMAs active period, and number of vessel transits (that consisted of at least $1 \mathrm{n}$ mile of travel within the DMA) by vessel type that were detected within the DMAs during their active period

\begin{tabular}{|c|c|c|c|c|c|c|c|c|c|c|c|c|c|}
\hline DMA & $\begin{array}{l}\text { No. of } \\
\text { whales }\end{array}$ & $\begin{array}{c}\text { Area } \\
\text { n miles }{ }^{2} \text { ) }\end{array}$ & Start date & End date & Tanker & Cargo & Passenger & Pilot & Sovereign & Tow & Tug & Other & Total \\
\hline NE_01 & 11 & 1767 & $12 / 11 / 2008$ & $12 / 25 / 2008$ & 11 & 1 & 0 & 1 & 0 & 11 & 11 & 8 & 43 \\
\hline NE_02 & 43 & 1576 & $12 / 11 / 2008$ & $12 / 28 / 2009$ & 6 & 0 & 0 & 0 & 0 & 0 & 0 & 0 & 6 \\
\hline NE_03 & 3 & 1356 & $12 / 11 / 2008$ & $12 / 25 / 2009$ & 21 & 3 & 0 & 0 & 0 & 0 & 0 & 0 & 24 \\
\hline NE_04 & 28 & 1997 & 1/13/2009 & 2/10/2009 & 39 & 14 & 0 & 0 & 0 & 23 & 32 & 17 & 125 \\
\hline NE_05 & 3 & 1605 & $1 / 16 / 2009$ & $1 / 29 / 2009$ & 32 & 21 & 3 & 0 & 0 & 20 & 19 & 10 & 105 \\
\hline NE_06 & 6 & 1448 & $2 / 11 / 2009$ & $2 / 25 / 2009$ & 14 & 6 & 0 & 0 & 0 & 5 & 7 & 3 & 35 \\
\hline NE_07 & 5 & 1456 & 2/11/2009 & $2 / 25 / 2009$ & 27 & 18 & 0 & 0 & 1 & 3 & 5 & 5 & 59 \\
\hline NE_08 & 12 & 2419 & $2 / 11 / 2009$ & $2 / 25 / 2009$ & 12 & 18 & 0 & 0 & 1 & 0 & 0 & 5 & 36 \\
\hline NE_09 & 3 & 1592 & $3 / 17 / 2009$ & $3 / 28 / 2009$ & 1 & 0 & 0 & 0 & 0 & 0 & 0 & 0 & 1 \\
\hline NE_10 & 5 & 1764 & $4 / 13 / 2009$ & $4 / 25 / 2009$ & 0 & 1 & 0 & 0 & 0 & 0 & 0 & 0 & 1 \\
\hline NE_11 & 15 & 1926 & $5 / 12 / 2009$ & $5 / 27 / 2009$ & 13 & 4 & 0 & 0 & 0 & 0 & 0 & 6 & 23 \\
\hline NE_12 & 3 & 1602 & $5 / 13 / 2009$ & $5 / 27 / 2009$ & 22 & 1 & 0 & 0 & 0 & 0 & 1 & 3 & 27 \\
\hline NE_13 & 44 & 4391 & 6/2/2009 & $6 / 29 / 2009$ & 41 & 30 & 8 & 0 & 1 & 1 & 0 & 21 & 102 \\
\hline NE_14 & 3 & 4391 & $7 / 9 / 2009$ & $7 / 21 / 2009$ & 20 & 22 & 3 & 0 & 3 & 0 & 0 & 24 & 72 \\
\hline NE_15 & 5 & 1644 & 9/2/2009 & 9/16/2009 & 8 & 2 & 4 & 0 & 0 & 2 & 0 & 15 & 31 \\
\hline NE_16 & 26 & 2124 & $10 / 15 / 2009$ & $11 / 11 / 2009$ & 18 & 5 & 11 & 0 & 0 & 17 & 17 & 30 & 98 \\
\hline NE_17 & 24 & 1918 & $10 / 22 / 2009$ & 12/1/2009 & 49 & 2 & 1 & 0 & 2 & 1 & 0 & 4 & 59 \\
\hline NE_18 & 16 & 2441 & $10 / 27 / 2009$ & $11 / 10 / 2009$ & 9 & 2 & 2 & 0 & 0 & 2 & 0 & 0 & 15 \\
\hline NE_19 & 41 & 3661 & $11 / 10 / 2009$ & $12 / 17 / 2009$ & 71 & 15 & 6 & 0 & 2 & 7 & 10 & 37 & 148 \\
\hline NE_20 & 47 & 3403 & $11 / 10 / 2009$ & $11 / 24 / 2009$ & 19 & 9 & 0 & 0 & 0 & 0 & 0 & 1 & 29 \\
\hline NE_21 & 27 & 4198 & $12 / 4 / 2009$ & $12 / 19 / 2009$ & 7 & 0 & 0 & 0 & 0 & 0 & 0 & 0 & 7 \\
\hline NE_22 & 37 & 3768 & $1 / 4 / 2010$ & 1/15/2010 & 3 & 0 & 0 & 0 & 0 & 0 & 0 & 0 & 3 \\
\hline NE_23 & 13 & 1887 & $1 / 5 / 2010$ & $1 / 28 / 2010$ & 34 & 6 & 0 & 0 & 0 & 10 & 13 & 10 & 73 \\
\hline NE_24 & 3 & 1527 & $2 / 1 / 2010$ & $2 / 15 / 2010$ & 0 & 0 & 0 & 0 & 1 & 4 & 0 & 2 & 7 \\
\hline NE_25 & 14 & 1922 & $3 / 8 / 2010$ & $3 / 22 / 2010$ & 1 & 0 & 5 & 0 & 0 & 1 & 0 & 1 & 8 \\
\hline NE_26 & 6 & 1697 & $3 / 12 / 2010$ & $3 / 24 / 2010$ & 7 & 11 & 0 & 0 & 0 & 0 & 0 & 3 & 21 \\
\hline NE_27 & 8 & 1941 & $3 / 22 / 2010$ & 4/4/2010 & 15 & 19 & 10 & 0 & 1 & 1 & 0 & 1 & 47 \\
\hline NE_28 & 3 & 1566 & $4 / 14 / 2010$ & $4 / 28 / 2010$ & 0 & 0 & 15 & 0 & 1 & 1 & 0 & 5 & 22 \\
\hline NE_29 & 18 & 886 & $4 / 22 / 2010$ & $5 / 5 / 2010$ & 25 & 16 & 2 & 0 & 5 & 9 & 33 & 25 & 115 \\
\hline NE_30 & 80 & 1682 & $4 / 30 / 2010$ & $5 / 5 / 2010$ & 8 & 9 & 3 & 0 & 3 & 7 & 16 & 15 & 61 \\
\hline NE_31 & 11 & 2460 & $5 / 24 / 2010$ & $6 / 5 / 2010$ & 20 & 10 & 2 & 0 & 0 & 0 & 2 & 12 & 46 \\
\hline NE_32 & 3 & 1591 & $7 / 27 / 2010$ & 8/9/2010 & 21 & 22 & 5 & 3 & 1 & 7 & 16 & 50 & 125 \\
\hline NE_33 & 4 & 1591 & 8/9/2010 & $8 / 23 / 2010$ & 26 & 19 & 9 & 4 & 3 & 8 & 11 & 55 & 135 \\
\hline NE_34 & 10 & 1591 & $8 / 18 / 2010$ & 9/1/2010 & 24 & 22 & 6 & 2 & 2 & 9 & 14 & 52 & 131 \\
\hline NE_35 & 6 & 1591 & 9/1/2010 & 9/14/2010 & 16 & 15 & 11 & 4 & 1 & 8 & 12 & 30 & 97 \\
\hline NE_36 & 4 & 1707 & $9 / 13 / 2010$ & $9 / 25 / 2010$ & 5 & 1 & 8 & 0 & 0 & 0 & 0 & 0 & 14 \\
\hline NE_37 & 7 & 1591 & 9/13/2010 & 9/27/2010 & 27 & 19 & 20 & 8 & 1 & 10 & 20 & 16 & 121 \\
\hline NE_38 & 10 & 2308 & $10 / 14 / 2010$ & $10 / 28 / 2010$ & 13 & 1 & 6 & 0 & 0 & 0 & 0 & 7 & 27 \\
\hline NE_39 & 8 & 1818 & $10 / 14 / 2010$ & $10 / 28 / 2010$ & 14 & 10 & 14 & 2 & 0 & 3 & 13 & 14 & 70 \\
\hline NE_40 & 4 & 1471 & $10 / 14 / 2010$ & $10 / 28 / 2010$ & 1 & 2 & 1 & 0 & 0 & 0 & 0 & 0 & 4 \\
\hline NE_41 & 14 & 1818 & $10 / 28 / 2010$ & 11/8/2010 & 10 & 4 & 2 & 0 & 3 & 2 & 6 & 6 & 33 \\
\hline NE_42 & 10 & 3754 & $11 / 16 / 2010$ & $11 / 27 / 2010$ & 24 & 24 & 1 & 0 & 0 & 3 & 20 & 8 & 80 \\
\hline NE_43 & 14 & 2760 & $11 / 16 / 2010$ & $11 / 27 / 2010$ & 7 & 9 & 0 & 0 & 0 & 0 & 0 & 2 & 18 \\
\hline NE_44 & 12 & 2447 & $11 / 16 / 2010$ & $11 / 27 / 2010$ & 0 & 1 & 0 & 0 & 0 & 0 & 0 & 1 & 2 \\
\hline NE_45 & 7 & 2299 & $11 / 29 / 2010$ & $12 / 14 / 2010$ & 15 & 2 & 0 & 0 & 2 & 5 & 9 & 8 & 41 \\
\hline NE_46 & 16 & 2413 & 12/1/2010 & $12 / 14 / 2010$ & 4 & 0 & 0 & 0 & 0 & 0 & 0 & 0 & 4 \\
\hline NE_47 & 4 & 1683 & 12/1/2010 & $12 / 14 / 2010$ & 9 & 0 & 0 & 0 & 0 & 0 & 0 & 1 & 10 \\
\hline NE_48 & 28 & 4032 & $12 / 21 / 2010$ & 1/2/2011 & 24 & 13 & 0 & 0 & 0 & 1 & 0 & 0 & 38 \\
\hline NE_49 & 5 & 1561 & $12 / 21 / 2010$ & $1 / 2 / 2011$ & 2 & 1 & 0 & 0 & 0 & 0 & 0 & 1 & 4 \\
\hline NE_50 & 3 & 1579 & $1 / 4 / 2011$ & $1 / 15 / 2011$ & 15 & 5 & 0 & 0 & 1 & 2 & 6 & 2 & 31 \\
\hline NE_51 & 4 & 1680 & $1 / 4 / 2011$ & $1 / 15 / 2011$ & 1 & 0 & 0 & 0 & 0 & 0 & 0 & 0 & 1 \\
\hline NE_52 & 8 & 2108 & $1 / 4 / 2011$ & $1 / 15 / 2011$ & 2 & 0 & 0 & 0 & 0 & 0 & 0 & 0 & 2 \\
\hline NE_53 & 3 & 1592 & $1 / 10 / 2011$ & $1 / 23 / 2011$ & 86 & 196 & 13 & 0 & 3 & 33 & 23 & 18 & 372 \\
\hline NE_54 & 5 & 1612 & $2 / 25 / 2011$ & $3 / 11 / 2011$ & 11 & 28 & 21 & 0 & 2 & 0 & 1 & 1 & 64 \\
\hline NE_55 & 5 & 1813 & $3 / 15 / 2011$ & $3 / 29 / 2011$ & 3 & 6 & 0 & 0 & 0 & 0 & 0 & 1 & 10 \\
\hline NE_56 & 3 & 899 & $4 / 27 / 2011$ & $5 / 10 / 2011$ & 0 & 1 & 18 & 0 & 1 & 5 & 6 & 8 & 39 \\
\hline
\end{tabular}


Table 1 (continued)

\begin{tabular}{|c|c|c|c|c|c|c|c|c|c|c|c|c|c|}
\hline DMA & $\begin{array}{l}\text { No. of } \\
\text { whales }\end{array}$ & $\begin{array}{c}\text { Area } \\
\left(\text { miles }^{2} \text { ) }\right.\end{array}$ & Start date & End date & Tanker & Cargo & Passenger & Pilot & Sovereign & Tow & Tug & Other & Total \\
\hline NE_57 & 13 & 1995 & $5 / 2 / 2011$ & $5 / 15 / 2011$ & 8 & 12 & 10 & 0 & 3 & 13 & 19 & 18 & 83 \\
\hline NE_58 & 21 & 648 & $5 / 3 / 2011$ & $5 / 17 / 2011$ & 13 & 22 & 0 & 0 & 6 & 1 & 0 & 10 & 52 \\
\hline NE_59 & 21 & 1163 & $5 / 3 / 2011$ & $5 / 17 / 2011$ & 8 & 18 & 0 & 0 & 2 & 0 & 0 & 9 & 37 \\
\hline SE_01 & 16 & 693 & $1 / 12 / 2010$ & $2 / 5 / 2010$ & 0 & 0 & 0 & 0 & 0 & 2 & 2 & 3 & 7 \\
\hline SE_03 & 19 & 774 & $2 / 1 / 2010$ & $3 / 24 / 2010$ & 0 & 0 & 0 & 0 & 0 & 3 & 6 & 3 & 12 \\
\hline SE_05 & 33 & 1476 & $2 / 22 / 2010$ & $3 / 15 / 2010$ & 12 & 35 & 29 & 0 & 1 & 34 & 14 & 13 & 138 \\
\hline SE_07 & 8 & 673 & $1 / 12 / 2011$ & $1 / 27 / 2011$ & 0 & 2 & 0 & 0 & 0 & 0 & 0 & 1 & 3 \\
\hline SE_08 & 4 & 635 & 1/31/2011 & $2 / 15 / 2011$ & 0 & 1 & 0 & 0 & 0 & 1 & 1 & 1 & 4 \\
\hline SE_09 & 5 & 404 & $2 / 24 / 2011$ & $3 / 11 / 2011$ & 0 & 1 & 0 & 0 & 0 & 1 & 1 & 1 & 4 \\
\hline SE_10 & 5 & 845 & $2 / 28 / 2011$ & $3 / 15 / 2011$ & 7 & 44 & 0 & 0 & 0 & 3 & 4 & 4 & 62 \\
\hline Totals & 905 & & & & 961 & 781 & 249 & 24 & 53 & 279 & 370 & 607 & 3324 \\
\hline
\end{tabular}

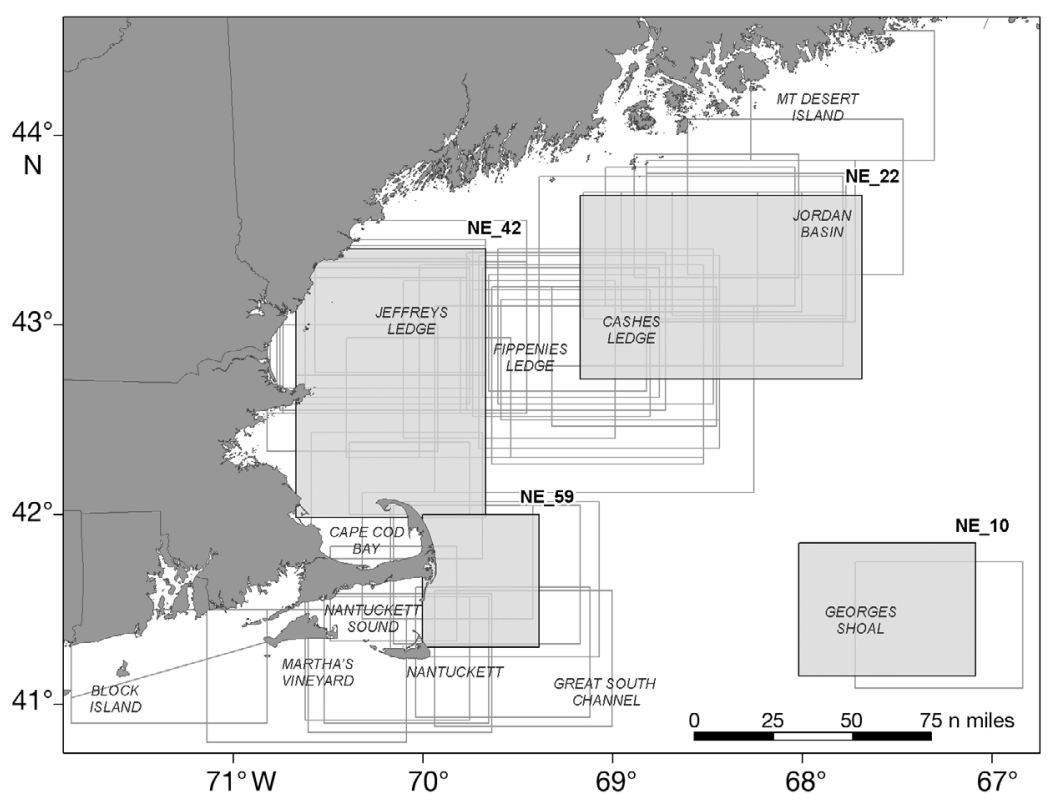

Fig. 1. Boundaries of dynamic management areas (DMAs) located in waters off New England. DMAs NE_10, NE_22, NE_42, and NE_59 have been labeled and shaded to illustrate variation in size and shape ing and immediately following the active DMA times. Vessel speeds were examined to determine if basic vessel operations changed in response to the DMAs. We calculated mean and median speeds within DMAs and compared speeds within DMAs to those in $10 \mathrm{n}$ mile buffer areas surrounding DMAs to determine if vessel operators changed atsea speeds in response to the DMAs. To ensure representative travel speeds, we limited the speed analyses to those trips that consisted of at least $5 \mathrm{n}$ miles of uninterrupted travel at speeds of 5 knots or greater both inside the DMAs and in the $10 \mathrm{n}$ mile buffers around them. Shipping industry consultations indicated that any anticipated course or speed modifications would occur within $5 \mathrm{n}$ miles of a management area. We (arbitrarily) doubled the size of this study area to ber of designations, such as cargo, tanker, passenger, tow, pilot, tug, and sovereign (i.e. those owned or operated by a national government), and we used these same designations in our analysis. For characterization of use of the areas by vessel type, we developed an 'other' category that included, for example, fishing vessels, sailing or pleasure craft, sovereign, dredging, and diving vessels when these were indicated by the operator.

For comparative purposes, we studied operations within the 66 DMAs relative to operations in $10 \mathrm{n}$ mile 'buffer' areas surrounding the DMAs. We also compared operations in periods when the DMAs were active relative to $2 \mathrm{wk}$ periods directly preced-
$10 \mathrm{n}$ miles. Vessels may continue to transmit AIS signals while at anchor or in port. Therefore, to reduce the amount of unneeded data (e.g. those indicating a speed of 0 knots) and to consider vessels actually underway, we analyzed speed data for only those vessels traveling $>5$ knots. Our use of vessel speed throughout refers to the vessel's 'speed over ground' (SOG) as provided in the AIS signal. Vessel speeds within the DMAs were compared to those in the corresponding $10 \mathrm{n}$ mile buffer areas using a Wilcoxon signed-rank test. This comparison was made for all vessels combined, as well as for the following 3 vessel types: cargo, tanker, and passenger. Center, spread, outliers, and interquartile 
range, or middle $50 \%$ of the transit speeds, were also determined for the transits. Transit speeds greater than the 75 th percentile plus 3 times the interquartile range were represented as outliers.

We also examined vessel routes to determine if vessel operators altered course to avoid a DMA. For vessels with transits that were located entirely within the $10 \mathrm{n}$ mile buffer, a hypothetical shortest-possible route was created using the vessel's first and last positions. If the hypothetical shortest-possible route intersected the DMA, we considered the transit a potential avoidance transit (Fig. 2). We conducted this analysis for transits initiated during the effective periods, as well as for the 2 wk periods directly preceding and following the effective periods.

\section{RESULTS}

A total of 3324 trips consisting of at least $1 \mathrm{n}$ mile were made by 1100 individual vessels through active DMAs. The average number of transits per DMA was 50 and ranged from 1 to 372 . The majority of transits were made by tankers $(\mathrm{n}=961)$, followed by cargo vessels $(\mathrm{n}=781)$ and tugs $(\mathrm{n}=370)$. Of the 1100 unique vessels, 769 were foreign-flagged.

Of the 3324 transits analyzed, 1799 included at least $5 \mathrm{n}$ miles of uninterrupted travel at speeds of 5 knots or greater both inside the DMAs and $10 \mathrm{n}$ mile buffers outside DMAs and thus were in-

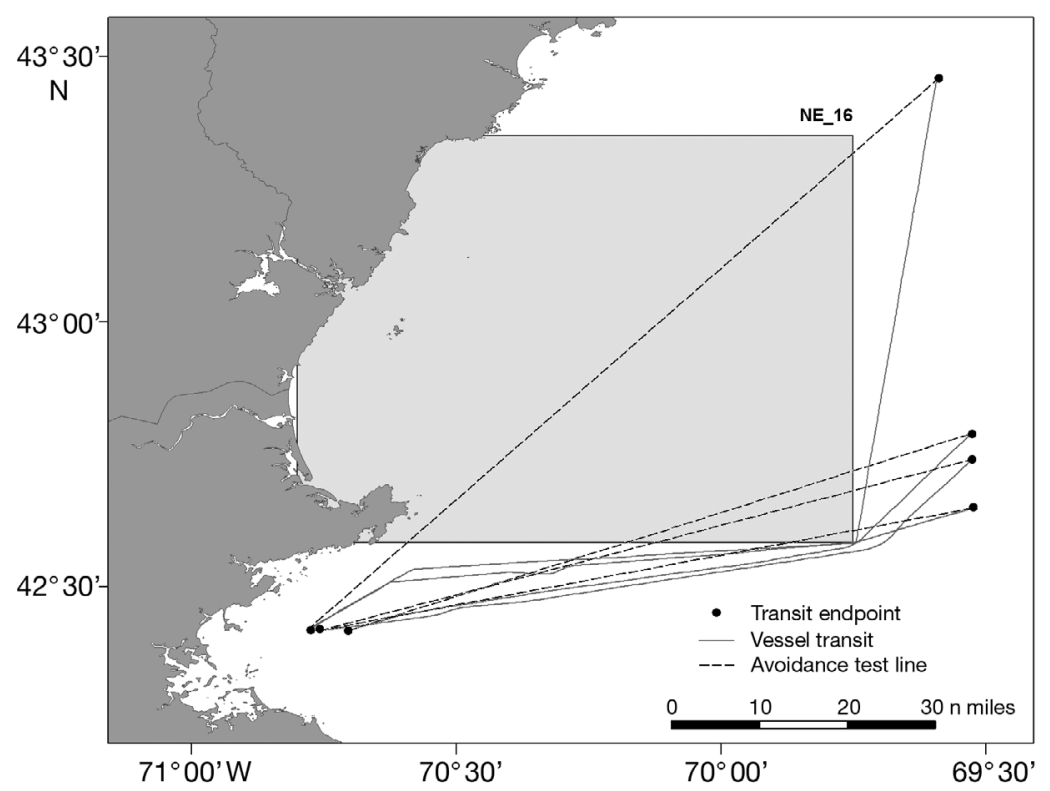

Fig. 2. Four vessel transits around dynamic management area (DMA) NE_16 in which courses may have been altered to avoid travel through the management area. See 'Vessel operations in DMAs' in 'Materials and methods' cluded in the vessel speed analyses. The 1799 transits were made by 745 individual vessels, 557 of which were foreign-flagged. On average, speeds in active DMAs were greater than the requested limit of $\leq 10$ knots (mean $=12.0, \mathrm{SD}=3.91$ ). Differences in median speeds in DMAs (Mdn $=11.4)$ as compared to their adjoining buffer areas $(\mathrm{Mdn}=12.0)$ were statistically significant $(Z=5.96, \mathrm{p}<$.001) (Fig. 3); however, the differences were small, and reductions in speeds were not great enough to universally comply with the requested 10 knot limit. We found similar relationships among cargo, tanker, and passenger vessel types. Mean speeds by tanker and cargo vessels were $<0.5$ knots lower inside DMAs than in their respective buffer areas. The largest difference in speeds was observed for passenger vessels, whose mean speeds in the $10 \mathrm{n}$ mile buffer areas and DMAs were 16.05 and 14.10 knots, respectively. Considering individual trips, however, 599 of the 1799 analyzed had mean speeds equal to or below the requested maximum of 10 knots; of those, 166 had mean speeds above 10 knots prior to entering the DMA.

Potential avoidance transits were observed in the active periods of only 18 of the 66 DMAs analyzed (Table 2). In 7 of these 18 (all of which occurred off New England), potential avoidance transits were observed only during the active period and not in the $2 \mathrm{wk}$ periods before and after the DMA went into effect. However, in the remainder (i.e. 11 of 18) of the DMAs in which apparent course changes were made, we also detected avoidance transits in the 2 wk period directly preceding and/or following the DMA active period. This suggests that other factors likely played a role in determining routes chosen by operators that we attributed to 'avoidance', regardless of whether a DMA had been established. For example, vessel operators may have been responding instead to other navigational measures lying adjacent to or near those areas in which DMAs were imposed, including the existence of recommended routes in waters off Georgia/Florida and a traffic separation scheme and an 'Area To Be Avoided' off New England (see www.nmfs.noaa.gov/pr/shipstrike/ for descriptions of locations of each of these) immediately adjacent to a DMA. 

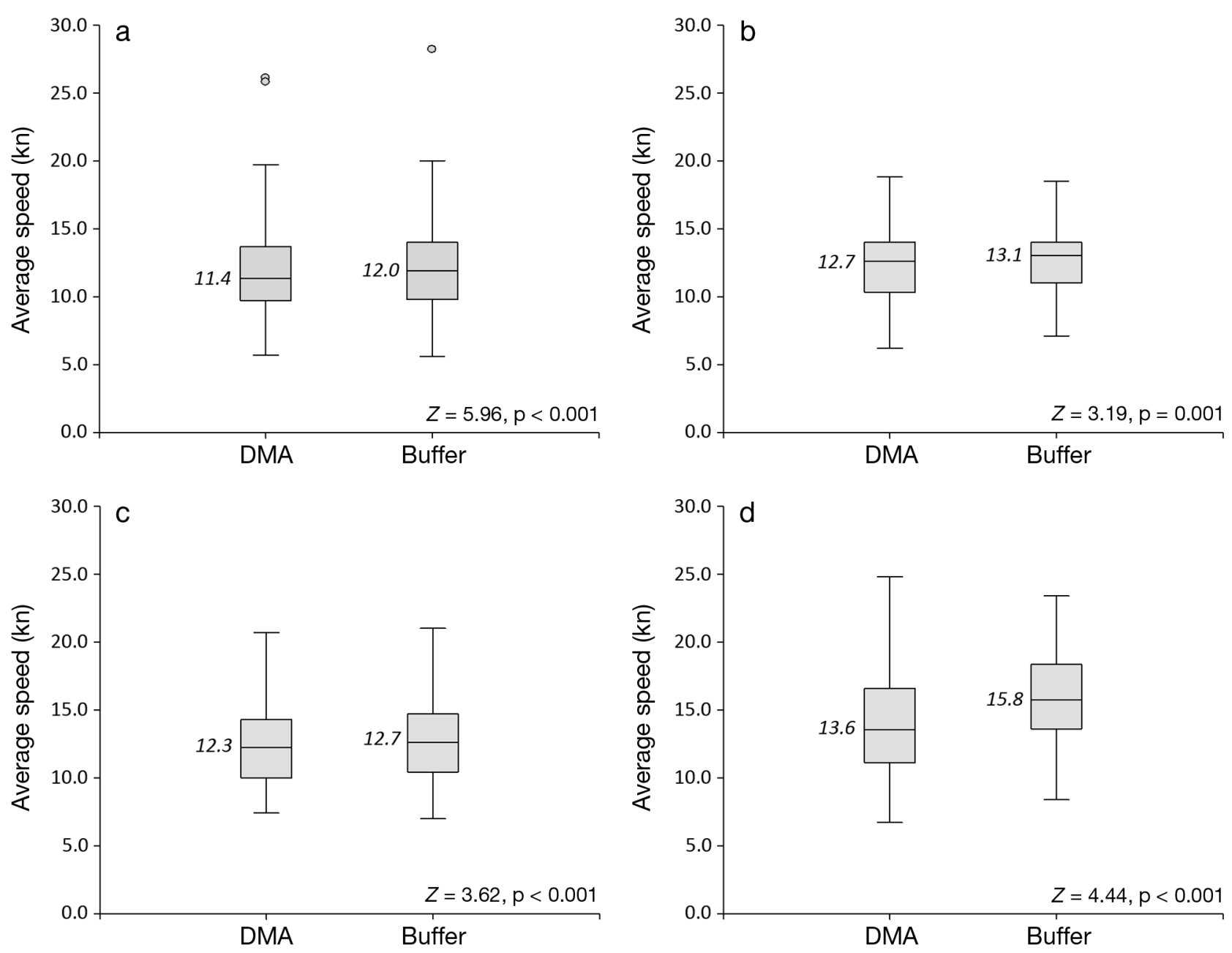

Fig. 3. Box plots of average vessel transit speeds within the dynamic management areas (DMAs) and 10 nautical mile buffers located outside of the DMAs for (a) all vessels combined, (b) tanker vessels, (c) cargo vessels, and (d) passenger vessels. Median speeds, represented by bars inside of the box plots, are provided along with the results from the Wilcoxon signed-rank tests. Data values greater than the 75th percentile plus 3.0 times the interquartile range are shown as outliers (o)

\section{DISCUSSION}

A number of measures involving changes in vessel operations have been implemented in various regions around the world to reduce the threat of vessel collisions with endangered large whale species. These include both mandatory and voluntary vessel speed restrictions and changes to vessel routes. Levels of vessel operator participation in heeding these measures appeared to be mixed. For example, mariner adherence with voluntary measures that include an 'Area To Be Avoided' (e.g. Vanderlaan et al. 2009), 3 modified traffic separation schemes (Tejedor et al. 2007, Vanderlaan et al. 2008, Silber et al. 2012), and recommended routes (Lagueux et al. 2011) tended to be high. In contrast, Wiley et al. (2008) found that adherence to guidelines for whale- watch vessels was low, and compliance with both voluntary and mandatory vessel speed restrictions has also been low, at least initially (Silber \& Bettridge 2010). The relative success of some measures may depend upon their being endorsed by the International Maritime Organization (Silber et al. 2012), the efficacy of outreach or monitoring and mariner notification programs, or may suggest vessel operators are more likely to adhere to voluntary routing measures than those involving vessel speed reductions.

We made the assumption that vessel operators were adequately notified about the management areas, but we were not able to confirm this. Therefore, a better understanding is needed about why the outcome of this program was less than expected. Factors may include, for example, that notification of the management areas was not universally received by 
Table 2. Number of 'avoidance transits' (see 'Results' for a definition of this term) detected for the dynamic management areas (DMAs) during their respective active periods and during the 2 wk immediately preceding and following their active periods. Only those DMAs in which avoidance transits were detected are listed

\begin{tabular}{|c|c|c|c|c|}
\hline \multirow[t]{2}{*}{ DMA } & \multirow[t]{2}{*}{ Vessel type } & \multicolumn{3}{|c|}{ Avoidance transits } \\
\hline & & Before & During & After \\
\hline NE_04 ${ }^{\mathrm{a}}$ & Tanker & 0 & 4 & 0 \\
\hline NE_07 & Tug & 1 & 1 & 1 \\
\hline NE_08 & Tanker & 1 & 1 & 0 \\
\hline NE_11 ${ }^{\mathrm{a}}$ & Tanker & 0 & 1 & 0 \\
\hline NE_13 & Tanker & 0 & 1 & 1 \\
\hline NE_14 ${ }^{\mathrm{a}}$ & Tanker & 0 & 1 & 0 \\
\hline \multirow[t]{2}{*}{ NE_15 } & Passenger & 0 & 3 & 1 \\
\hline & Tanker & 0 & 1 & 1 \\
\hline \multirow[t]{2}{*}{ NE_16 ${ }^{\mathrm{a}}$} & Passenger & 0 & 2 & 0 \\
\hline & Tanker & 0 & 2 & 0 \\
\hline NE_17 $7^{\mathrm{a}}$ & Passenger & 0 & 1 & 0 \\
\hline \multirow[t]{2}{*}{ NE_18 } & Passenger & 0 & 1 & 0 \\
\hline & Tanker & 0 & 0 & 2 \\
\hline \multirow[t]{2}{*}{ NE_31 } & Other & 0 & 1 & 0 \\
\hline & Tanker & 0 & 0 & 1 \\
\hline NE_33 ${ }^{\mathrm{a}}$ & Tanker & 0 & 1 & 0 \\
\hline NE_38 ${ }^{a}$ & Passenger & 0 & 1 & 0 \\
\hline \multirow[t]{5}{*}{ NE_57 } & Cargo & 1 & 0 & 0 \\
\hline & Other & 0 & 0 & 1 \\
\hline & Pleasure & 0 & 0 & 1 \\
\hline & Sailing & 0 & 0 & 2 \\
\hline & Tanker & 5 & 2 & 1 \\
\hline \multirow[t]{2}{*}{ NE_58 } & Sailing & 1 & 0 & 0 \\
\hline & Tug & 0 & 2 & 2 \\
\hline SE_03 & Towing & 0 & 0 & 1 \\
\hline \multirow[t]{3}{*}{ SE_05 } & Cargo & 0 & 1 & 0 \\
\hline & Pleasure & 0 & 0 & 1 \\
\hline & Tug & 0 & 1 & 1 \\
\hline \multirow[t]{4}{*}{ SE_10 } & BigTow & 1 & 0 & 0 \\
\hline & Cargo & 7 & 5 & 7 \\
\hline & Dredging & 1 & 0 & 0 \\
\hline & Tanker & 0 & 1 & 0 \\
\hline
\end{tabular}

vessel operators, they were received but ignored, atsea conditions precluded slowing to $10 \mathrm{knots}$, or other factors. However, the studies needed to make these determinations are beyond the scope of this one.

We analyzed and presented these data in rather broad terms (e.g. mean speeds) to assess the overall effectiveness of the program at an affected population level, but this approach may obscure some changes in behavior (e.g. changes in speeds) made by individual vessels or segments of the population. It appears, for example, that operators of passenger vessels made somewhat greater attempts than those operating other vessel types to alter their operations in response to DMAs. Additional analysis is likely needed to determine, with greater specificity, if individual vessel operators or certain segments of this community were aware of and made attempts to comply with the requests made through this program. Such analysis is advisable to further assess the utility of the program or specific aspects of it.

Voluntary conservation measures are generally preferable to those that are mandated because the former are more readily implemented and have fewer administrative costs (Alberini \& Segerson 2002), do not require development of enforcement programs, and have various benefits derived from willing participation. However, data are not always available to determine if compliance with such initiatives is actually occurring, and we herewith add to the handful of studies in which compliance has been measured in regards to reducing vessel-strikes. We found that, when taken in the aggregate, mariners exhibited real and detectable, but generally low levels of adherence with requests to alter speed or course. Therefore, this program likely had only a modest consequence in reducing the occurrence of vessel collisions with right whales Eubalaena glacialis.

Public voluntary programs may have the tacit benefits of improved environmental protection that results from community-wide dissemination of information even if changes in behavior are not quantified (Lyon \& Maxwell 2007), and it is possible this is an unintended benefit of the program we studied. However, the lackluster response of vessel operators to DMAs suggests only moderate success of the program in achieving its goals and that the NMFS may want to re-evaluate the utility of the program and consider, for example, doing away with it to devote energy to more effective ship-strike reduction measures, or altering it to enhance its effectiveness perhaps by making certain actions within DMAs mandatory and enforceable.

Our findings may have application to other settings where voluntary environmental conservation actions are contemplated or undertaken. If they are used, consideration should be given to establishing realistic, agreed-upon baselines (Morgenstern \& Pizer 2007) and reasonable expected outcomes; developing means to engage, notify, and ensure adherence by the affected communities; and creating monitoring programs that enable periodic assessment the program's overall conservation value (Alberini \& Segerson 2002, Vanderlaan \& Taggart 2009, Silber et al. 2012). 
Acknowledgements. We thank Kam Chin and David Phinney of the John A. Volpe National Transportation Systems Center for their assistance and guidance in the acquisition and analysis of vessel AIS data. Tim Cole, Barb Zoodsma, and Mike Asaro run the right whale sightings and DMA analysis programs at NMFS's Northeast and Southeast Fisheries Science Centers and Regional Offices. The USCG National AIS program has been invaluable to this and other vessel operation analyses.

\section{LITERATURE CITED}

Alberini A, Segerson K (2002) Assessing voluntary programs to improve environmental quality. Environ Resour Econ 22:157-184

Asaro MJ (2012) Geospatial analysis of dynamic management areas for protection of the North Atlantic right whale along the northern Atlantic coast of the United States. Mar Policy 36:915-921

Barde JP (2000) Environmental policy and policy instruments. In: Folmer H, Landis Gabel H (eds) Principles of environmental and resource economics: a guide for students and decision-makers. Fed Regist 71:69328-69358

Clapham PJ, Pace RM III (2001) Defining triggers for temporary area closures to protect right whales from entanglements: issues and options. Fisheries Science Center Ref Doc 01-06, NEFSC, NOAA, Woods Hole, MA

European Environment Agency (EEA) (1997) Environmental agreements: environmental effectiveness. Env Iss Series No. 3, Vol 1-2, EEA, Copenhagen

FWS/NMFS (Fish and Wildlife Service/National Marine Fisheries Service) (1997) Endangered species habitat conservation planning handbook. NMFS, NOAA, Washington, DC

Gamper-Rabindran S (2006) Did the EPA's voluntary industrial toxics program reduce plants' emissions? A GIS analysis of distributional impacts and a by-media analysis of substitution. J Environ Econ Manage 52:391-410

Glass AH, Cole TVN, Garron M, Merrick RL, Pace RM III (2008) Mortality and serious injury determinations for baleen whale stocks along the United States eastern seaboard and adjacent Canadian Maritimes, 2002-2006. Northeast Fish Sci Cent Ref Doc 08-04, NEFSC, NOAA, Woods Hole, MA

Glass AH, Cole TVN, Garron M (2010) Mortality and serious injury determinations for baleen whale stocks along the United States eastern seaboard and adjacent Canadian Maritimes, 2004-2008. NOAA Tech Mem NMFS-NE214, NEFSC, NOAA, Woods Hole, MA

Jensen AS, Silber GK (2003) Large whale ship strike database. NOAA Tech Mem NMFS-F/OPR-25, NMFS, Silver Spring, MD

Khanna M (2001) Non-mandatory approaches to environmental protection. J Econ Surv 15:291-324

Khanna M, Damon LA (1999) EPA's voluntary 33/50 program: impact on toxic releases and economic performance of firms. J Environ Econ Manage 37:1-25

Kraus SD, Brown MW, Caswell H, Clark CW and others (2005) North Atlantic right whales in crisis. Science 309: 561-562

Lagueux KM, Zani MA, Knowlton AR, Kraus SD (2011) Response by vessel operators to protection measures for right whales Eubalaena glacialis in the southeast US calving ground. Endang Species Res 14:69-77

Laist DW, Knowlton AR, Meade JG, Collet AS, Podesta M (2001) Collisions between ships and whales. Mar Mamm Sci 17:35-75

Lyon TP, Maxwell JW (2007) Environmental public voluntary programs reconsidered. Policy Stud J 35:723-750

Mönkkönen M, Ylisirniö AL, Hämäläinen T (2009) Ecological efficiency of voluntary conservation of boreal-forest biodiversity. Conserv Biol 23:339-347

Morgenstern RD, Pizer WA (eds) (2007) Reality check: the nature and performance of voluntary environmental programs in the United States, Europe and Japan. RFF Press, Washington, DC

NOAA (National Oceanic and Atmospheric Administration) (2008a) Area to be avoided 'In the Great South Channel'. Proposal to the international maritime organization's sub-committee on safety of navigation. International Maritime Organization, London

NOAA (National Oceanic and Atmospheric Administration) (2008b) Final rule: speed restrictions to reduce the threat of ship collisions with North Atlantic right whales. US Dep Commer Fed Regist 73:60173-60191

NPS (National Park Service) (2006) Glacier Bay National Park: vessel management plan regulations US Dep Inter Fed Regist 71:69328-69358

NRC (National Research Council) (2002) New tools for environmental protection: education, information and voluntary measures. In: Dietz T, Stern PC (eds) Division of Behavioral and Social Sciences and Education, National Academy Press, Washington, DC, p 368

Pace RM, Silber GK (2005) Simple analysis of ship and large whale collisions: Does speed kill? In: Proceedings 16th biennial conference on the biology of marine mammals? Society for Marine Mammalogy, San Diego, CA (Abstract)

- Rivera J, de Leon P (2004) Is greener whiter? Voluntary environmental performance of western ski areas. Policy Stud J 32:417-437

Silber GK, Bettridge S (2006) United States' actions to reduce the threat of ship collisions with North Atlantic right whales. International Whaling Commission Conservation Committee's Working Group on Ship Strikes, International Whaling Commission, London

Silber GK, Bettridge S (2010) Vessel operations in right whale protection areas in 2009. NOAA Tech Mem NMFS-OPR-44, Office of Protected Resources, Silver Spring, MD

Silber GK, Vanderlaan ASM, Tejedor Arceredillo A, Johnson L and others (2012) Role of the International Maritime Organization in large whale vessel strike reduction: processes, measures and effectiveness. Mar Policy 36:1221-1233

Smith RBW, Shogren JF (2002) Voluntary incentive design for endangered species protection. J Environ Econ Manag 43:169-187

Tejedor A, Sagarminaga R, Cañadas A, de Stephanis R, Pantoja J (2007) Modifications of maritime traffic off southern Spain. Scientific Committee of the International Whaling Commission SC/59/BC13, London

Tejedor Arceredillo A, Sagarminaga R, Stephanis RD, Canadas A, Lago A (2008) Management of MPAs: options and challenges for the maritime transport sector. In: Workshop at the 21st annual meeting of the ECS: selection criteria for marine protected areas for cetaceans ECS Spec Publ Ser 48:93-98 
Van Waerebeek K, Baker AN, Felix F, Gedamke J and others (2007) Vessel collisions with small cetaceans worldwide and with large whales in the Southern Hemisphere, an initial assessment. Latin American J Aq Mamm 6: 43-69

Vanderlaan ASM, Taggart CT (2007) Vessel collisions with whales: the probability of lethal injury based on vessel speed. Mar Mamm Sci 23:144-156

Vanderlaan ASM, Taggart CT (2009) Efficacy of a voluntary area to be avoided to reduce risk of lethal vessel strikes to endangered whales. Conserv Biol 23: 1467-1474

Vanderlaan ASM, Taggart CT, Serdynska AR, Kenney RD, Brown MW (2008) Reducing the risk of lethal encounters:

Editorial responsibility: Ana Cañadas, Madrid, Spain vessels and right whales in the Bay of Fundy and on the Scotian Shelf. Endang Species Res 4:283-297

- Vanderlaan ASM, Corbett JJ, Green SL, Callahan JA, and others (2009) Probability and mitigation of vessel encounters with North Atlantic right whales. Endang Species Res 6:273-285

Waring GT, Josephson E, Maze-Foley K, Rosel PE (eds) (2010) US Atlantic and Gulf of Mexico marine mammal stock assessments - 2010. NOAA Tech Mem NMFS-NE219, NEFSC, NOAA, Woods Hole, MA

Wiley DN, Moller JC, Pace RM III, Carlson C (2008) Effectiveness of voluntary conservation agreements: case study of endangered whales and commercial whale watching. Conserv Biol 22:450-457

Submitted: February 16, 2012; Accepted: April 17, 2012 Proofs received from author(s): June 15, 2012 